Type of the Paper (Article)

\title{
Title: Structure and Composition of Plant Vegetation in Urban Area of Dhaka South City Corporation, Bangladesh
}

\author{
Md. Shahariar Jaman ${ }^{* *}$, Ishrat Jahan ${ }^{1}$ Mahbuba Jamil ${ }^{2}$, Md. Golam Jilani Helal ${ }^{1}$, Md. Shariful \\ Islam ${ }^{1}$, Md. Javed Azad ${ }^{3}$ and Md. Forhad Hossain ${ }^{1}$
}

${ }^{1 *}$ Assistant Professor, Department of Agroforestry and Environmental Science, Sher-e-Bangla Agricultural University, Sher-e-Bangla Nagar, Dhaka-1207 ; shmishu.sau@gmail.com / shmishu2287@sau.edu.bd

${ }^{1}$ Masters research fellow, Department of Agroforestry and Environmental Science, Sher-e-Bangla Agricultural University, Sher-e-Bangla Nagar, Dhaka-1207 ; ishrat.agr.2010@gmail.com

${ }^{2}$ Agriculture Extension Officer, Government of People's Republic of Bangladesh; tithi0412@gmail.com

${ }^{1}$ Assistant Professor, Department of Agroforestry and Environmental Science, Sher-e-Bangla Agricultural University, Sher-e-Bangla Nagar, Dhaka-1207 ; helalsau093636@gmail.com

${ }^{1}$ Assistant Professor, Department of Agroforestry and Environmental Science, Sher-e-Bangla Agricultural University, Sher-e-Bangla Nagar, Dhaka-1207 ; sharifulsbh@gmail.com

${ }^{3}$ Assistant Professor, Department of Agricultural Extension and Information System, Sher-e-Bangla Agricultural University, Sher-e-Bangla Nagar, Dhaka-1207 ; mishad.16dec@gmail.com

1Professor, Department of Agroforestry and Environmental Science, Sher-e-Bangla Agricultural University, Sher-e-Bangla Nagar, Dhaka-1207 ; forhadsau@gmail.com

* Correspondence: shmishu.sau@gmail.com; Tel.: +88-01710490942

Abstract: Plants are an important feature of urban ecosystems which provide numerous environmental and ecosystem benefits such as defenses against noise and air pollution and conservation of biodiversity. The aim of this study was to investigate the structure and composition of urban vegetation in different urban habitats like roadsides, parks, gardens and playgrounds in Dhaka South City area. Stratified random sampling method was used in this study. A total of 221 plant species belonging to 63 families were identified and recorded. Among all plant species Swietenia macrophylla, Polyalthia longifolia, Cocos nucifera, Samanea saman, and Artocarpus heterophyllus are recorded as the most dominant. Most of the tree and shrub population were found between 6-9 $\mathrm{m}$ and $1-3 \mathrm{~m}$ height classes whereas most of tree and shrub population were found in between 10$15 \mathrm{~cm}$ dbh classes. Highest IVI was found for Swietenia macrophylla (193.22\%) followed by Polyalthia longifolia (184.59\%), Samanea saman (138.37\%), Cocos nucifera $(79.9 \%)$ and Delonix regia $(68.27 \%)$ respectively. Average frequency, density, dbh and basal area were found $46.82 \%, 138.28$ tree ha- ${ }^{-1}$, $458.59 \mathrm{~cm} \mathrm{ha}^{-1}$ and $12.33 \mathrm{~m}^{2} \mathrm{ha}^{-1}$ respectively. Findings of this study reveals that structural attributes of plant represent quite young and still developing vegetation. This research will help to plan for future green infrastructure which will maintain ecosystem function, therefore, providing longer term benefits for the city dwellers. 
Keywords: diameter at breast height; basal area; frequency; density; important value index

\section{Introduction}

Urban forest is one of the most important component of urban ecosystem that provide multiple service and environmental benefits to urban environment [1]. These environmental benefits may include conservation of energy, reduction of urban heat island effect, improve air and water quality, carbon sequestration and biodiversity conservation [2,3]. Urban forest also provide some social and economic benefits such as reduce psychological stress, quick recovery from illness, reduce health cost, improve the quality of microclimate and increase the property value $[4,5,6]$. Most of the city dwellers think that urban forest has the significant contribution to make the urban environment safe for city peoples and improve the better quality of life. The vegetation in urban area is a highly altered and dominated ecosystem in which structure and composition of species is determined by human actions $[7,8,9]$. The ecological processes and functions which enhance the environmental quality within urban areas are highly influenced by urban forest structure and composition [10,11]. Variation in sizes and species of trees in an urban forest ensures the diversity of structures which support the variety of values the urban forest provides [12]. An urban forest can be characterized in terms of composition, structure, and function [13] where structure means the spatial arrangement and characteristics of vegetation in relation to other objects (e.g. buildings, parks, roadsides etc.) within urban areas [14]. Species composition can be characterized as the number of plant species found in a landscape, including trees, shrubs, and herbs and it reflects different patterns of urban vegetation and modern land use system $[15,16]$. Forest structure indicates the distribution of vegetation, both horizontally and vertically, in a given area [17]. Basic information that is necessary to describe urban forest structure includes tree numbers, species composition, density, basal area and growing conditions [18]. Additionally, different urban sites such as private gardens, parks, green spaces or road networks may have different types of species composition [19,10, 20,11, 21].

In Bangladesh, conservation of biodiversity and forest is very essential especially in urban areas as they are suffering through extreme degradation because of high population growth, lack of awareness, motivational activities, over exploitation and rapid loss of natural resources [22]. According to UN-World Health Organization, $9 \mathrm{~m}^{2}$ per capita greenery area is required for environmental and other adjuvant services but the present situation of urban greenery in Dhaka city is so measurable and less than $2 \mathrm{~m}^{2}$ greenery space per capita is present [23]. So it is necessary to increase the green space and forestation by using all available land including park, playground, garden, alley and roadsides to minimize this critical situation. Many cities in the world especially European and American cities have represented their success by increasing the planting rate of different plant species in their urban city areas [1]. However, environmental biotic and abiotic factors in urban area sometimes not suitable for planting trees. Furthermore, most of the urban streets and 
footways are permanently construct with concrete which considered as one of the major barrier for tree plantation. Consequently, many factors determine the structure, composition, distribution and diversity of plant species in urban area [24]. Information on vegetative structure and floristic composition is indispensable in understanding the urban ecosystem dynamics [25]. Therefore, this research was attempted to evaluate the structure and composition of plant species which was helpful to know the existing urban vegetation and also help to increase the greenery and establishment of urban forest in Dhaka City because no systematic study has been performed yet to analyze the structure and composition of vegetative covers of existing green spaces in Dhaka city.

\section{Materials and Methods}

\subsection{Study Area}

The study was carried out in the Dhaka South City corporation area located along the bank of Buriganga river $\left(23^{\circ} 72^{\prime} 39^{\prime \prime} \mathrm{N}, 90^{\circ} 40^{\prime} 85^{\prime \prime} \mathrm{S}\right)$ covering an area of 109.19 square kilometer (Figure 1$)$. The city covering with a population of 7.56 million and the average density of 69,237 people $\mathrm{km}^{-2}$. It has 27 parks, 10 playgrounds, 3 gardens and 2 Cemeteries respectively which has the major contribution to cover the urban vegetation of this city [26]. Dhaka south city corporation area has $781.83 \mathrm{~km}$ roads and $217.38 \mathrm{~km}$ footway which contribute to make an urban forest structure through street tree species [27]. The whole city lies at the elevation of 6 to $8 \mathrm{~m}$ above sea level [28]. According to the geological origin of soils; it situated under the category of Modhupur soil tract (AEZ 28) which consists mainly of silt and clay [29]. Soil of the experimental site mainly belongs to the medium high land and its texture contains silt loam, olive-gray with common fine to medium distinct dark yellowish brown mottles and pH 5.6 [29]. The climatic condition is mostly tropical and humid. Cool and short winter with hot and long summer season is one of the major climatic condition of Dhaka.

(1)

(1)

. 
110 (a)

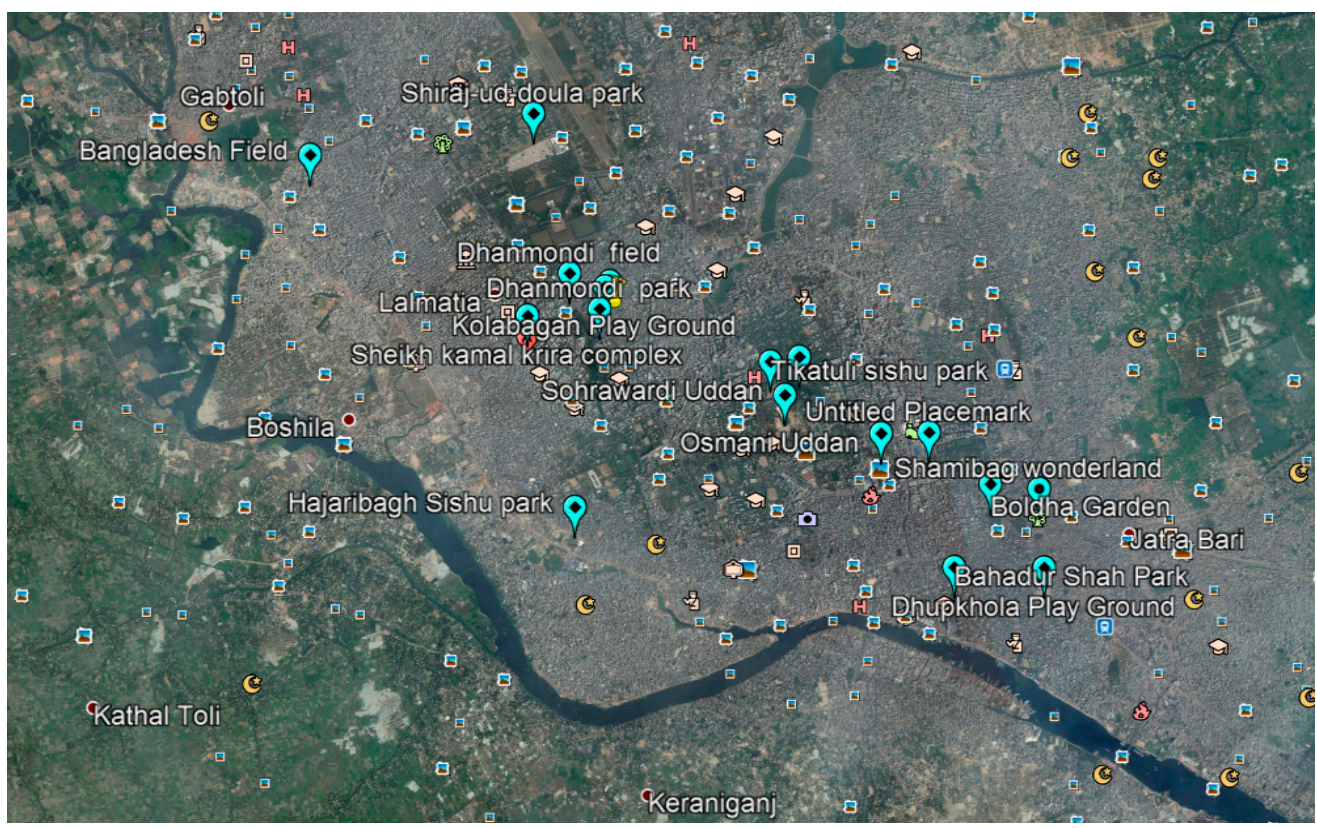

(c)

Figure 1. Location of the study area: (a) Bangladesh (b) Dhaka city and (c) Experimental plot location in Dhaka south city area (Source: googlepro software).

\subsection{Sampling and data collection}

Reconnaissance study was made to the experimental areas from July 2016 to December 2016 in order to get general information about the vegetation, accessibility to the parks, other green spaces and a list of all tree species was prepared. According to vegetation characteristics the whole study sites were divided into four categories (e.g. parks, playgrounds, gardens \& roadsides). A total of 192 sample plots (parks-80, playgrounds-10, gardens-49 \& roadsides-53) were taken and all plant 
122

123

124

125

126

127

128

129

130

population except herb in each quadrat were recorded. At each habitat types, the quadrates were divided into four specific sizes (park $15 \mathrm{~m} \times 5 \mathrm{~m}$, garden $15 \mathrm{~m} \times 5 \mathrm{~m}$, playground $10 \mathrm{~m} \times 5 \mathrm{~m}$ and roadside $20 \mathrm{~m} \times 5 \mathrm{~m}$ ). The number of each tree species was also quantified. The sampling areas were selected through random sampling method and quantitative assessment of structure and composition of tree covers was done by stratified random sampling method.

In parks and gardens, 20 meter plot to plot distance was maintained whereas in play grounds 10 meter distance was adopted. In roadsides, plots were taken in a zigzag manner on both the sides of road (Figure 2), in order to maintain variation and 100 meter plot to plot distance was maintained [30].

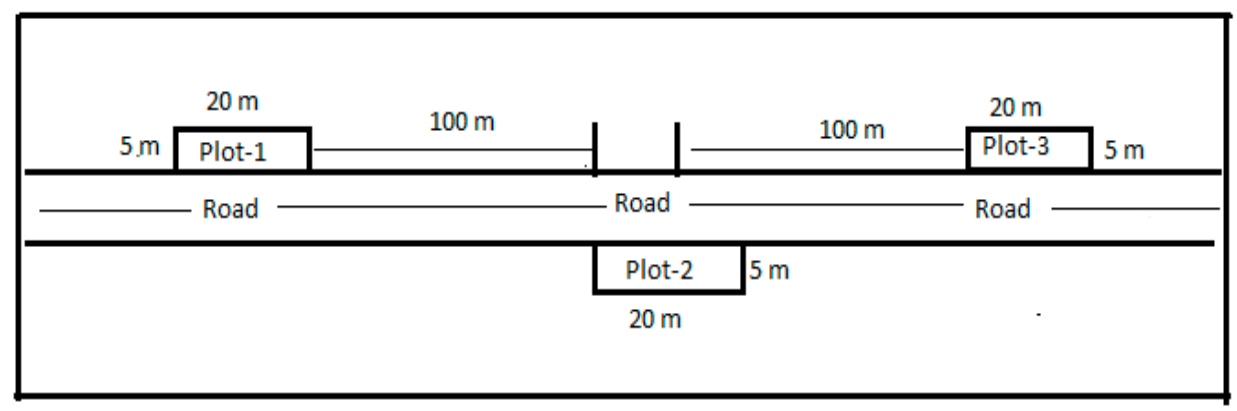

Figure 2. Sampling method of roadside.

133 The diameters of all identified trees \& shrubs were measured at breast height (1.3 $\mathrm{m}$ above ground) 134 using a diameter tape ( $5 \mathrm{~m}$ length). Diameter of individual trees were recorded to calculate basal area and relative basal area of plant species. Height of all sampling trees and shrubs were measured by haga altimeter using the following percentage scale formula:

$$
(\mathrm{TR}+\mathrm{BR}) \times \text { H.D }
$$

140 Where, $\mathrm{TR}=$ Top reading; $\mathrm{BR}=$ Bottom reading and $\mathrm{HD}=$ Horizontal

141 distance.

\subsection{Data analysis}

All the data was organized and analyzed by using MS Excel 2016, and statistical package for the social science (SPSS-11.5 statistics). One way ANOVA and post hoc $t$ test has been done to find out the significant difference among different parameters.

\subsection{Vegetation Structure}

147 The density $\left(\right.$ tree ha- $\left.{ }^{-1}\right)$, frequency $(\%)$, relative frequency $(\%)$, basal area $\left(\mathrm{m}^{2} \mathrm{ha}^{-1}\right)$, relative dominance 148 and Important Value Index (IVI) were calculated using the following formulas for quantitative 149 structure and composition of each trees and shrubs species [31,32,33]. 
150

151

152

153

154

155

156

157

158

159

160

161

162

163

164

165

166

167

168

169

170

171

172

173

174

175

176

177

178

179

180

181 182 183

184

185

Total number of plots in which the species occurs

1. Density $\left(\right.$ tree ha-1 $\left.^{-1}\right)=$

Total number of plots studied

Total number of individuals of one species in all the plots

2. Relative density $(\%)=$

Total number of plots studied

Total number of plots in which the species occurs

3. Frequency $(\%)=$

Total number of plots studied

Frequency of one species

4. Relative frequency $=$

Sum of frequency of all species

Total basal area of individual species

5. Basal area $\left(\mathrm{m}^{2} \mathrm{ha}^{-1}\right)=$

Sample plot area (ha) x Total number of plots studied

Total basal area of one species in all plots

6. Relative Basal area (\%) x100

Total basal area of all species in all plots

7. Importance value Index $(\%)=($ Relative density + Relative frequency + Relative dominance $) / 3$

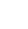

(1)

.

7 8 9 1 
7 of 21

186

187

188

189

190

191

192

193

194

195

196

197

198

199

200

(1)

\section{Results}

\subsection{Number of plant population and size of the study area}

By comparing the number of species and the size of different study area indicates that with increase area size, the number of plant species increases as well. Park area (0.6 ha) showed the highest number of individual $(\mathrm{n}=1478)$ followed by gardens $(0.37 \mathrm{ha}$; $\mathrm{n}=858)$, roadsides $(0.53$ ha; $\mathrm{n}=856)$ and playgrounds (0.05 ha; $\mathrm{n}=134)$ respectively (Figure 3 ).

Figure 3. Distribution of plant according to size of the study area.

\subsection{Relationship between study area and vegetative characteristics}

By compering mean dbh $(\mathrm{cm})$ and basal area $\left(\mathrm{m}^{2} \mathrm{ha}^{-1}\right)$ with four different type of study sites it is observed that mean $\mathrm{dbh}(\mathrm{cm})$ positively correlated with area size but slightly negative trend observed in case of basal area. Highest dbh was shown by parks (0.6ha) with the value of $20.99 \mathrm{~cm}$ and lowest value was found in playgrounds $(0.05 \mathrm{ha}, 17.05 \mathrm{~cm})$. Similarly for basal area, the highest value was $8.18 \mathrm{~m}^{2} \mathrm{ha}^{-1}$ found in playgrounds and the lowest was $1.30 \mathrm{~m}^{2} \mathrm{ha}^{-1}$ in gardens (Figure 4).

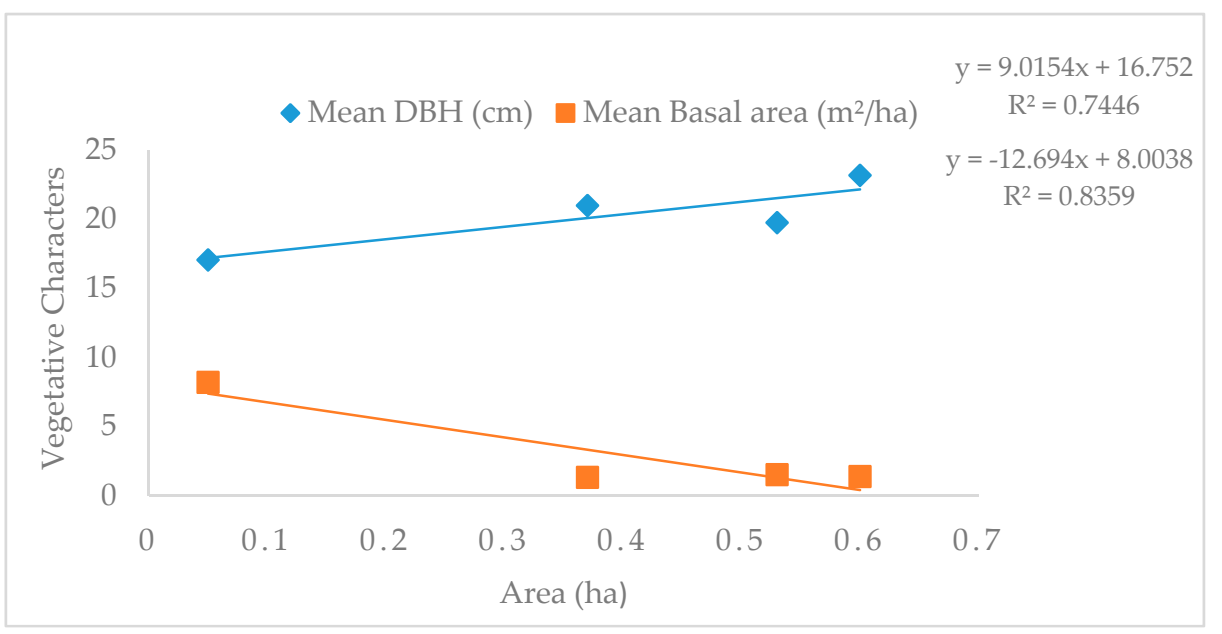

Figure 4. Relationship between area and vegetative characteristics among four different study sites. 
204

205

206

207

208

209

210

211

212

213

214

215

216

217

218

219

220

221

222

223

224

225

226

\subsection{Relationship between area with frequency and density}

The graph shows a relationship between frequency and density with different study areas where both of them show the negative trend. Highly negative relationship observed in case of frequency and small negative relationship found in case of density. This figure also indicates that, playground $(0.05$ ha) shows relatively higher frequency (22.41) and density (92.4) rather than gardens ( $F=7.7, D=15.56)$, parks $(\mathrm{F}=6.33, \mathrm{D}=12.91)$ and roadsides $(\mathrm{F}=10.38, \mathrm{D}=17.41)$ and the values are gradually decreased in the order of playground >roadsides $>$ gardens $>$ parks (Figure 5).

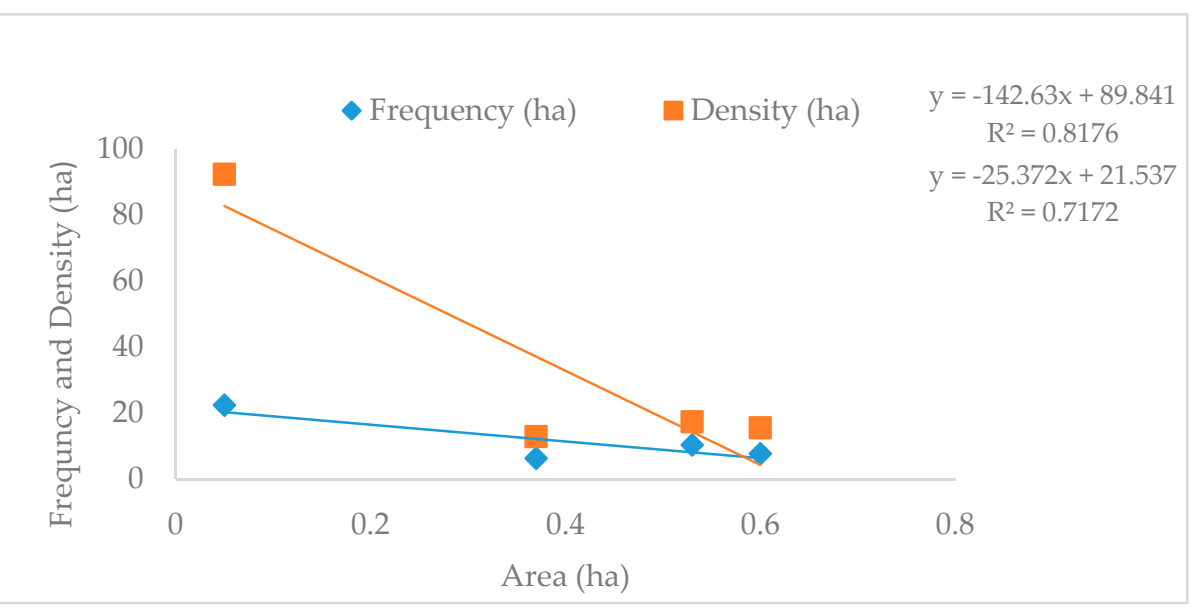

Figure 5. Relationship between area size (ha) with frequency (\%) and density (\%) of four different study area.

\subsection{Distribution of number of plant along with different plant height}

For the height structure, the classes were defined at regular intervals of $3 \mathrm{~m}$ and the height classes are categorized in comparison between areas. Differences in plant height among four categories of study areas were not statistically significant. In parks, maximum numbers of trees and palms $(n=214 \& n=$ 47) were enlisted in between 6.2-9.1m height class where maximum numbers of shrubs $(n=252)$ were found in between 3.2-6.1m height class. Similarly, in gardens, maximum numbers of trees and palms $(\mathrm{n}=156$ \& $\mathrm{n}=22)$ were enlisted in 6.2-9.1m height class and shrubs $(\mathrm{n}=128)$ in between $3.2-6.1 \mathrm{~m}$ height class. Maximum numbers of trees $(n=39)$, palms $(n=6)$ and only 2 shrub species were found between 6.2-9.1 $\mathrm{m}$ and 3.2-6.1 $\mathrm{m}$ height classes in playground whereas roadsides contained maximum numbers of trees $(n=177)$ in 6.2-9.1m height and maximum numbers of palms $(n=29)$ and shrubs $(n=54)$ between 9.2-12.1m and 1-3.1 $\mathrm{m}$ height class respectively (Figure 6). Trees and palms from almost all of the study areas were found in between 6-9 $\mathrm{m}$ height class indicated that most of the trees are quite smaller in height. 


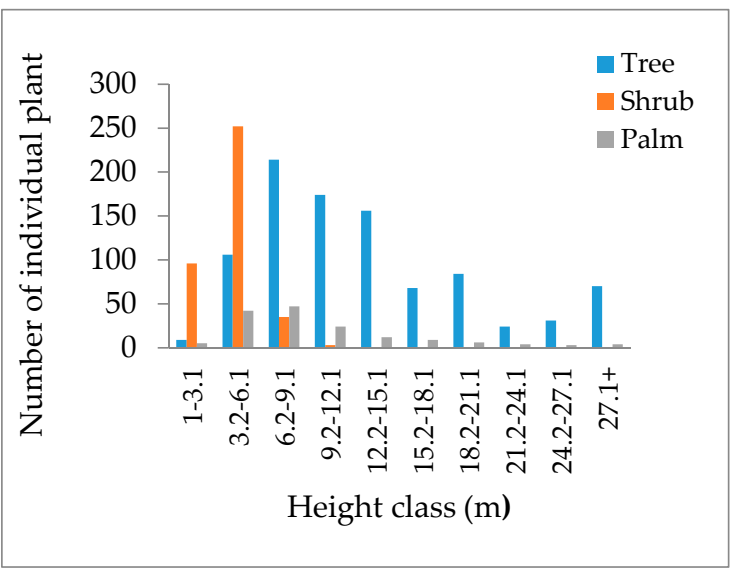

(a)

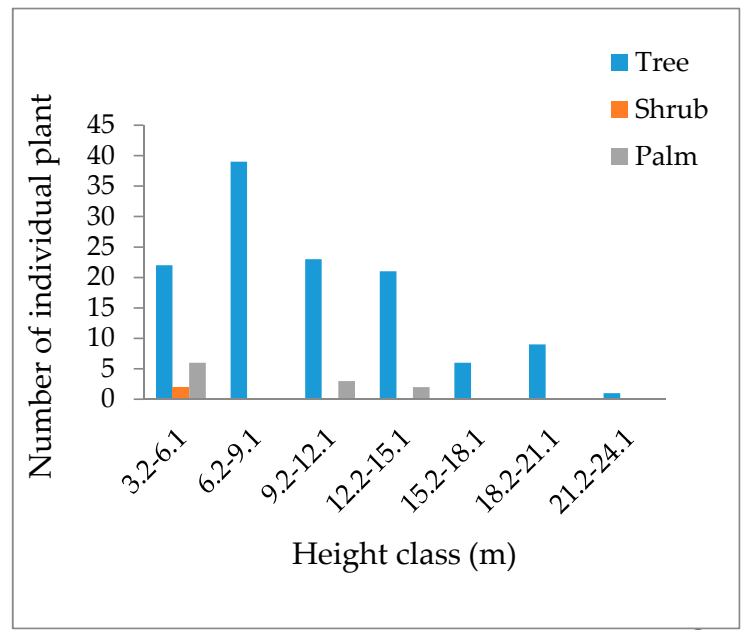

(c)

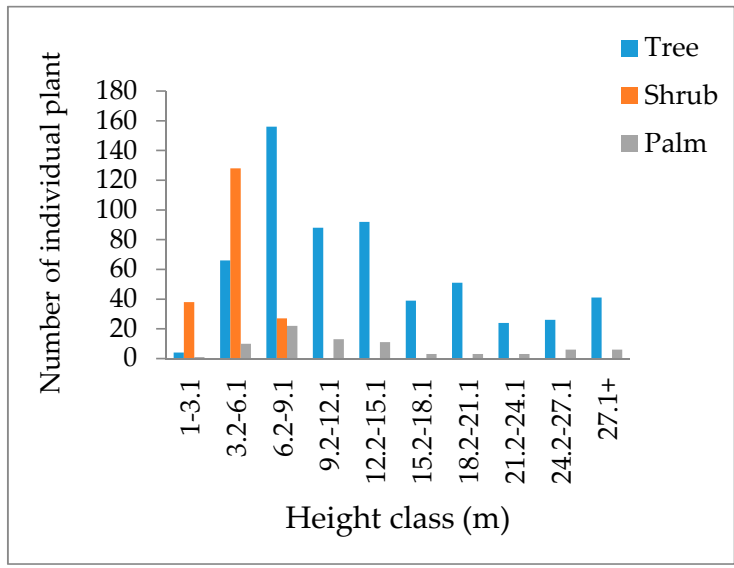

(b)

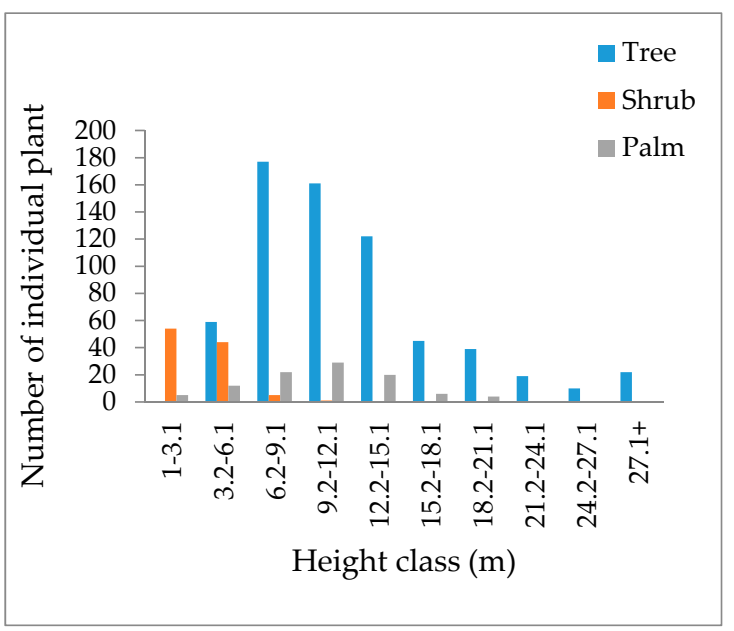

(d)

Figure 6. Distribution of number of individual along with different plant height classes among four different study areas (a) Park (b) Garden (c) Playground (d) Roadside.

\subsection{Distribution of number of individual along with different dbh classes}

In case of dbh, the classes were defined at regular intervals of $15 \mathrm{~cm}$ to improve the comparison between areas. It was observed that the differences in dbh among four categories of study areas were not statistically significant. In parks, maximum number of tree population $(n=270)$ were enlisted in between $16-30 \mathrm{~cm}$ dbh class and maximum number of shrub and palm population $(\mathrm{n}=501 \& \mathrm{n}=49)$ were found in between $0-15 \mathrm{~cm}$ dbh class. Number of tree, shrub and palm in gardens $(n=205 ; n=209$; $n=25)$, playgrounds $(n=57 ; n=2 ; n=8)$ and roadsides $(n=283 ; n=110 ; n=46)$ was found in same $(0-15 \mathrm{~cm})$ dbh class (Figure 7).

However, maximum number of plant population belongs to the $0-15 \mathrm{~cm}$ dbh class in DSCC. Majority of plant population showed lower $\mathrm{dbh}$ and the number of individual plants decreased with the increase of diameter class in these study area. Significant variation observed in playground because shrubs and palm mostly absent in playground. 


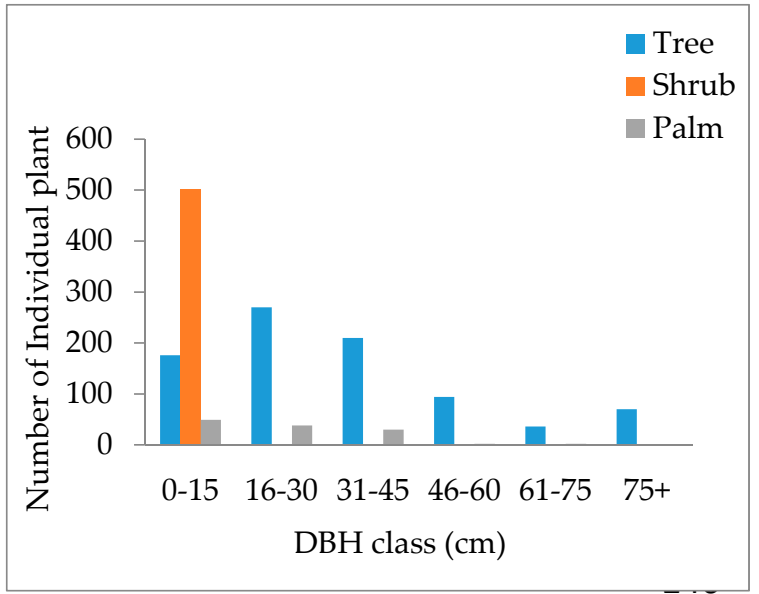

(a)

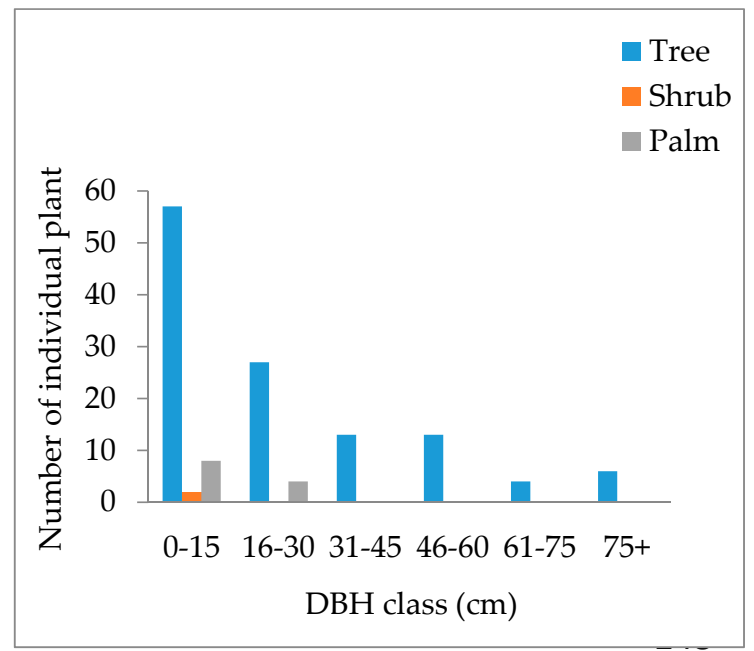

(c)

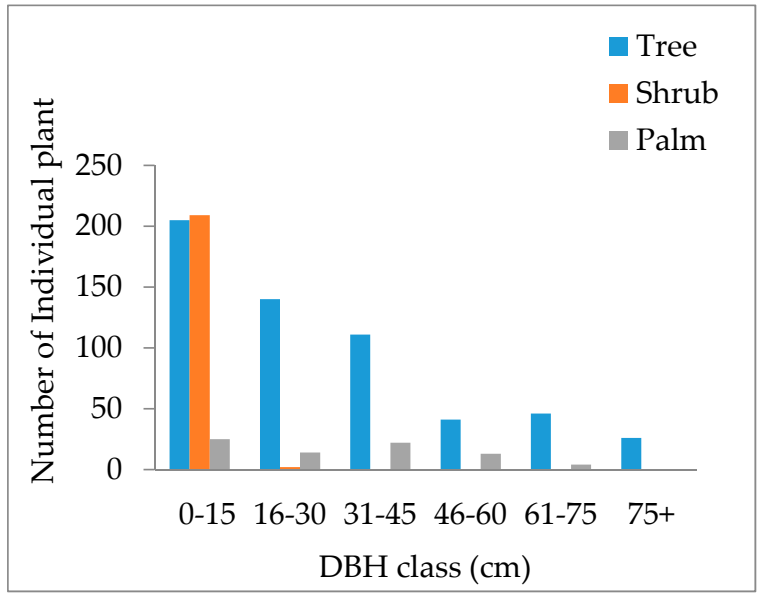

(b)

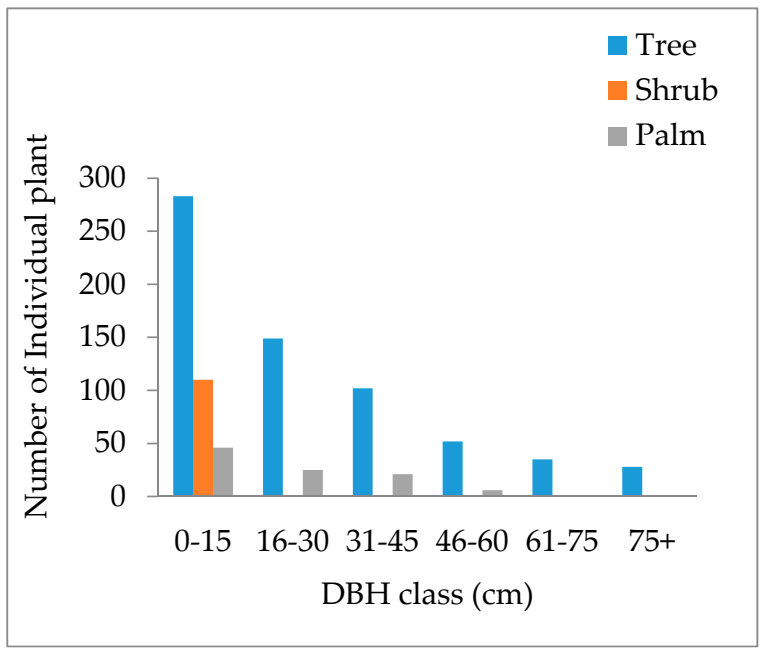

(d)

250 Figure 7. Distribution of number of individual along with different $\mathrm{dbh}(\mathrm{cm})$ classes among four

251 different study area (a) Park (b) Garden (c) Playground (d) Roadside.

\subsection{Distribution of plant species according to the category of the study area}

254 The bar graph shows the percent of plant species in four different types of study area (Figure 8).

255 Significant variation among tree, shrubs and palm observed in Playground and it contained higher 256 percent of tree species (90.29\%) but lower percent of shrubs (1.49\%) and palm (6.2\%) species. Little 257 variation has found in parks (trees=62.99\%, shrubs=26.45\%, palms=10.55\%) and gardens 258 (trees $=68.18 \%$, shrubs $=22.72 \%$, palms=9.09\%) whereas in roadsides shrub $(13.20 \%)$ and palm $(11.42 \%)$ species shown no significant variation (Figure 8). 


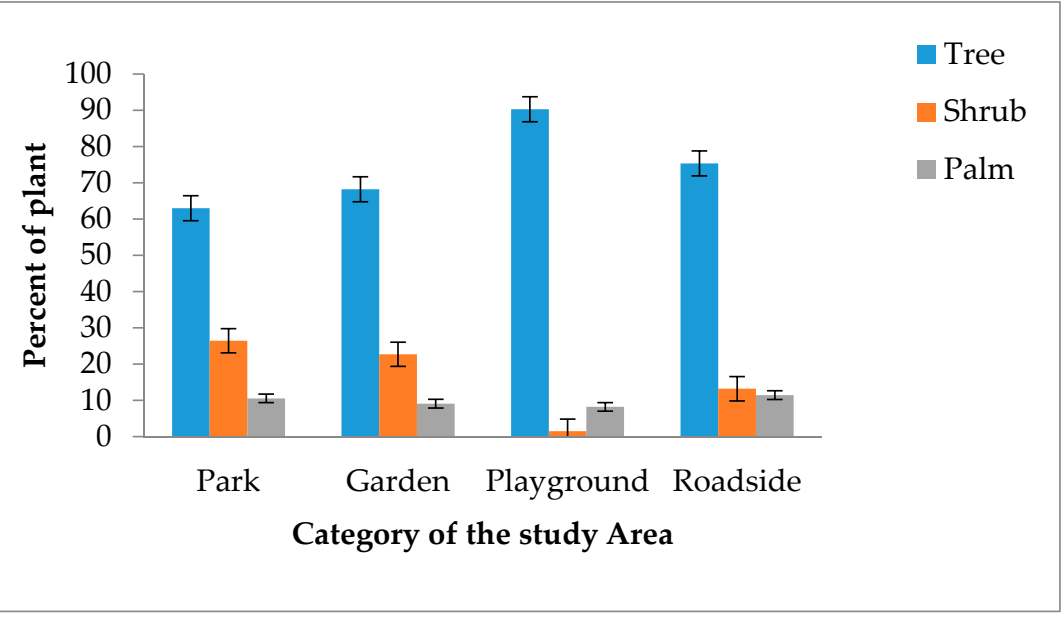

261 Figure 8. Distribution of plant species according to the category of the study area.

$262 \quad 3.7$ Vegetation Structure

263 Plant vegetation structure and composition represent the overall structural features of park, roadside,

264 garden and playground in DSCC. Ranges of frequency (\%), density (trees ha-1), and basal area $\left(\mathrm{m}^{2}\right.$ ha-

$265{ }^{1}$ ) in four different study sites varied from 1.25-80.00, 1.67-600.00 and 0.01-113.91 respectively, where

266 highest mean frequency, density and basal area observed after total 10 plot studied in playground

$267(\mathrm{~F}=22.41 \pm 4.38, \mathrm{D}=92.41 \pm 11.87, \mathrm{BA}=8.18 \pm 4.67)$ and lowest frequency and density found in park ( $\mathrm{F}=$

$2686.33 \pm 2.80$ and $\mathrm{D}=12.91 \pm 4.30$ ) in total 80 plot studied. Only different is basal area which was lowest

269 in garden $(1.29 \pm 1.56)$ (Table 1$)$.

270

Table 1. Frequency, density and Basal area of four different study area.

\begin{tabular}{|c|c|c|c|c|c|c|}
\hline Area & Frequency (\%) & Range & Density ha-1 & Range & Basal area $\left(m^{2} h^{-1}\right)$ & Range \\
\hline & & Min $\quad$ Max & & Max & & Min \\
\hline Park & $6.33 \pm 2.80$ & $1.25-43.75$ & $12.91 \pm 4.30$ & $1.67-138.33$ & $1.36 \pm 1.71$ & $0.02-25.46$ \\
\hline Roadside & $10.38 \pm 3.23$ & $1.89-54.72$ & $17.40 \pm 4.71$ & $1.89-145.28$ & $1.50 \pm 1.78$ & $0.01-21.51$ \\
\hline Garden & $7.70 \pm 2.70$ & $2.04-36.73$ & $15.56 \pm 4.18$ & $2.72-84.35$ & $1.29 \pm 1.56$ & $0.02-17.27$ \\
\hline Playground & $22.41 \pm 4.38$ & $10.0-80.0$ & $92.41 \pm 11.87$ & $20.0-600.0$ & $8.18 \pm 4.67$ & $0.02-113.91$ \\
\hline
\end{tabular}

3.8 Species Diversity and Structure of Twenty Most Dominant Species.

273 A total of 221 plant species belonging to 63 families were identified and recorded from 192 sampling

274 plot in four different study areas. Considering the relative density (RD), relative frequency (RF) and

275 relative dominance (RD), Swietenia macrophylla, Polyalthia longifolia, Samanea saman, and Cocos nucifera

276 were found most important plant species (Table 2). 
277 Distribution of plant according to their family represented that Fabaceae and Arecaceae were most

278 important and dominated family among the other families found in the study sites in respect of their

279 number of species $(28,14)$, number of genera $(22,13)$ and also total number of individual $(542,337)$

280 (Table 3).

Table 2. RF, RD, RBA \& IVI of twenty most dominant species in Dhaka south city area.

\begin{tabular}{|c|c|c|c|c|c|}
\hline $\begin{array}{l}\text { SL } \\
\text { No }\end{array}$ & Species name & $\begin{array}{l}\text { Relative } \\
\text { frequency }\end{array}$ & $\begin{array}{l}\text { Relative } \\
\text { density }\end{array}$ & $\begin{array}{c}\text { Relative } \\
\text { dominance }\end{array}$ & IVI \\
\hline 1. & Swietenia macrophylla & 240.61 & 304.7 & 34.35 & 193.22 \\
\hline 2. & Polyalthia longifolia & 308.8 & 231.39 & 13.58 & 184.59 \\
\hline 3. & Samanea saman & 67.84 & 166.13 & 182.64 & 138.87 \\
\hline 4. & Cocos nucifera & 198.8 & 143.45 & 5.73 & 115.99 \\
\hline 5. & Artocarpus heterophyllus & 28.49 & 145.09 & 4.41 & 59.33 \\
\hline 6. & Mimusops elengi & 27.53 & 162.7 & 7.83 & 66.02 \\
\hline 7. & Delonix regia & 47.72 & 140.71 & 16.38 & 68.27 \\
\hline 8. & Mangifera indica & 28.81 & 142.83 & 9.35 & 60.33 \\
\hline 9. & Ficus bengalensis & 106.6 & 81.42 & 8.72 & 65.58 \\
\hline 10. & Albizia richardiana & 8.88 & 94.43 & 35.92 & 46.41 \\
\hline 11. & Lagerstroemia speciosa & 14.4 & 103.73 & 5.5 & 41.21 \\
\hline 12. & Dypsis lutescens & 2.9 & 81.14 & 0.17 & 28.07 \\
\hline 13. & Tectona grandis & 25.53 & 88.96 & 4.76 & 39.75 \\
\hline 14. & Eucalyptus camaldulensis & 3.65 & 77.93 & 12.53 & 31.37 \\
\hline 15. & Terminalia arjuna & 24.01 & 75.23 & 9.72 & 36.32 \\
\hline 16. & Anthocephalus sinensis & 64.63 & 68.94 & 10.79 & 48.12 \\
\hline 17. & Dalbergia sissoo & 63.87 & 74.28 & 1.8 & 46.65 \\
\hline 18. & Acacia auriculiformis & 13.4 & 64.52 & 6.32 & 28.08 \\
\hline 19. & Mesua ferrea & 12.78 & 61.77 & 1.74 & 25.43 \\
\hline 20. & Syzygium cumini & 4.16 & 59.61 & 3.25 & 22.34 \\
\hline
\end{tabular}


Table 3. Number of species, genera and individual plant population according to the family.

\begin{tabular}{|c|c|c|c|c|}
\hline SL No. & Family & No of species & $\begin{array}{l}\text { No. of } \\
\text { genera }\end{array}$ & $\begin{array}{c}\text { No. of } \\
\text { individuals }\end{array}$ \\
\hline 1. & Fabaceae & 28 & 22 & 542 \\
\hline 2. & Arecaceae & 14 & 13 & 337 \\
\hline 3. & Moraceae & 13 & 5 & 211 \\
\hline 4. & Malvaceae & 11 & 11 & 74 \\
\hline 5. & Apocynaceae & 9 & 8 & 135 \\
\hline 6. & Euphorbiaceae & 8 & 7 & 86 \\
\hline 7. & Rutaceae & 8 & 4 & 47 \\
\hline 8. & Bignoniaceae & 7 & 7 & 23 \\
\hline 9. & Rubiaceae & 7 & 7 & 110 \\
\hline 10. & Myrtaceae & 7 & 5 & 143 \\
\hline 11. & Combrectaceae & 7 & 4 & 154 \\
\hline 12. & Lythraceae & 7 & 4 & 114 \\
\hline 13. & Solanaceae & 5 & 5 & 42 \\
\hline 14. & Meliaceae & 5 & 5 & 276 \\
\hline 15. & Annonaceae & 4 & 4 & 176 \\
\hline 16. & Anacardiaceae & 4 & 4 & 92 \\
\hline 17. & Sapotaceae & 4 & 3 & 107 \\
\hline 18. & Oleaceae & 4 & 2 & 38 \\
\hline 19. & Magnoliaceae & 4 & 2 & 10 \\
\hline 20. & Lecythidaceae & 3 & 3 & 45 \\
\hline
\end{tabular}




\section{Discussion}

\subsection{No of plant species}

A total of 221 plant species belonging to 63 families were identified and recorded from the study areas in Dhaka south city area. The number of species is quite lower compared to the 376 species (140 trees, 162 shrubs and 74 herbs) found in an urban forest, Lore lindu park of Indonesia [34] and 267 species (113 trees, 89 shrubs, 65 herbs) found in the eastern Terai of India [35]. However, 116 species (27 trees and 89 shrubs) in the urban forest of Fortaleza, Brazil [36] is quite lower than the present findings followed by 126 species ( 87 trees and 39 shrubs) found in the Shenyang city of China [37].

\subsection{Height class distribution}

Almost all of the study areas of Dhaka south city, trees were found in 6-9 m height class indicates most of the trees are quite smaller in height. In case of shrub species, most of them are 1-3.1m height class which means the shrub species represents adequate height because of regular pruning and other management practices. The findings of this study is lower than the research conducted in the metropolitan areas of Sylhet city, Bangladesh where 48 percent of trees were found in 9-12m height class [38]. In the deforested area of Chittagong, the maximum tree and shrub population was found in 3-4.9 m height which comparatively lower than present study value [39]. In urban parks of Sydney, majority of vegetation including trees and shrubs found between 5-20 m height [40]. In the Shenyang city of China, about $65 \%$ trees represent less than $10 \mathrm{~m}$ height [37].

\subsection{Dbh class distribution}

Trees and shrubs which has a placed with the urban living space are poor in diameter on account of various ecological elements like polluted sources, chemicals, dirt into the surrounding air, soil, and water. These factors are specifically impact on vegetation mortality and makes obstructions to wildlife life development.

Maximum number of tree and shrub species in present study areas belongs to the $0-15 \mathrm{~cm}$ dbh class. Maximum number of plant population showed lower $\mathrm{dbh}$ and the number of individual plants decreased with the increase of diameter class (Figure 7). This result represented lower dbh class value compared to the urban areas of Sao Paulo, Brazil where maximum native trees ( $>25 \%)$ were found in the $22.5-27.5 \mathrm{~cm}$ dbh class [41] but quite higher in comparison to the urban parks and recreation places of Chicago, USA where maximum number of plant population including trees and shrubs are found in the 1-3 cm dbh [42]. Most of the trees (about 76\%) in the Shenyang city, China, represent less than $20 \mathrm{~cm}$ in diameter which are almost similar with the present study [37]. Another study was conducted in vacant and commercial land at the Roanoke city of Virginia, USA found maximum number of trees and shrubs in 7.1-15.2 cm dbh class [43] which near similar to the findings of this study. In this research fewer number of individual tree were found with larger dbh values greater than $60 \mathrm{~cm}$ (dbh $>60 \mathrm{~cm}$ ) because of their growth form which can go up to this diameters [44]. 


\subsection{Distribution of plant species according to the category of the study area}

Playgrounds and streets of Dhaka south city have a scarcity of plant species compared to the garden and parks. Park contains highest percentage of plant population $(44 \%)$ whereas gardens and roadsides represent $26 \%$ of plants. Playgrounds represent the lowest plant population (4\%). Number of plant population are greatly related to the area size and the number of plot studied. A study was conducted in Barcelona city, Spain where parks have $43.10 \%$ and streets have $17.5 \%$ tree cover whereas in case of shrub, parks and streets contain 35\% and 3.2\% shrub population respectively [45]. Similar study was conducted in Shahiwal city, Pakistan found 74\% tree species present in Public Park whereas 55\% exotic and $45 \%$ local tree species in different institutions [46].

\subsection{Vegetation Structure}

Frequency, density and basal area were found $46.82 \%, 138.28$ tree ha-1 and $12.33 \mathrm{~m}^{2} \mathrm{ha}^{-1}$ respectively. Stem density 418 ha $^{-1}$ found in Kamalachori natural forest of Chittagong city, Bangladesh [47], 279 ha-1 in urban forest of Shenyang, China [48], 705 ha $^{-1}$ in urban roadsides of Taiwan [49], 369 ha $^{-1}$ in Bamu reserve forest of Cox's Bazar, Bangladesh [50], 376 ha $^{-1}$ in woodland of Metema area of northeastern Ethiopia [51] and $484 \mathrm{ha}^{-1}$ in forested landscape of central Himalayas [52]. These result are quite higher than the stem density of present study (parks, playground, gardens and roadside).

Basal area $15.3 \mathrm{~m}^{2} \mathrm{ha}^{-1}$ found in Kuandisha forest of northeastern Ethiopia, $102 \mathrm{~m}^{2} \mathrm{ha}^{-1}$ in Wof-Washa forest of Shewa, Ethiopia, $50 \mathrm{~m}^{2}$ ha-1 in Jibat forest, $45 \mathrm{~m}^{2}$ ha-1 $^{-1}$ in Denkoro forest, $115.4 \mathrm{~m}^{2}$ ha-1 $^{-1}$ in Tara Gedam forest of northwestern Ethiopia [53,54,55], $16.88 \mathrm{~m}^{2}$ ha-1 found in Chunati Wildlife Sanctuary Chittagong, Bangladesh [56], $27.07 \mathrm{~m}^{2} \mathrm{ha}^{-1}$ in Dudpukuria Dhopachori Wildlife Sanctuaries of Chittagong South Forest Division [57], $53.5 \mathrm{~m}^{2}$ ha-1 $^{-1}$ Chittagong hill tracts [58], $21.10 \mathrm{~m}^{2} \mathrm{ha}^{-1}$ in Kamalachori natural forest of Chittagong city, Bangladesh, [47], $16.88 \mathrm{~m}^{2} \mathrm{ha}^{-1}$ in Bamu reserve forest of Cox's Bazar, Bangladesh [50] and $47.02 \mathrm{~m}^{2}$ ha-1 $^{-1}$ in Tankawati natural forest of Chittagong, Bangladesh [59]. All of these result are also quite higher than the basal area of present study.

\subsection{Important Value Index (IVI)}

The importance value index (IVI) is an aggregate index that summarizes the density, abundance, and distribution of plant species [60]. IVI reflects the degree of dominance and abundance of a given species in relation to other species in an area [61,62]. Similarly, ecological significance of species can be identified in the study area through important value index [63].

Findings of this study showed the highest IVI for Swietenia macrophylla (193.22) followed by Polyalthia longifolia (184.59) and Samanea saman (138.87) (Table 2). Similar study was conducted in the urban parks of Bangalore, India where IVI value found for Polyalthia longfolia 34.9 [64], 28.37 for Swietenia macrophylla in the metropolitan area of Chittagong [65], 77.1 for Swietenia macrophylla in the urban forest of Sri Lanka [66] and 21.41 for Samanea saman, and 2.01 for Swietenia macrophylla in the roadsides of Southwestern Bangladesh [30]. The high Importance Value Index (IVI) of these species in green 
areas of Dhaka south city indicates their dominance, good power of regeneration, their growth habits and potential to tolerate diverse environmental condition of urban settlement.

\subsection{Composition of tree and shrub species according to family, genera and number of individuals} A total of 221 species distributed into 63 families and 135 genera identified in the study area of Dhaka south city (Table 3). The number of species, families and genera was higher in comparison to 72 species, 30 families and 65 genera found in the urban forest of Nigeria [67]. Another study conducted in the public land of Melbourne city, Australia found 399 species and 52 families [68]. Fabaceae was found as a richest family being represented by 28 species, 22 genera and 542 individuals followed by Arecaceae (14 species, 13 genera and 337 individuals), Meliaceae (5 species, 5 genera and 276 individuals) and Moraceae (13 species, 5 genera and 113 individuals). Fabaceae family also represented as the richest family with 18 species found in the urban forest of Brazil [36] and urban area of Congo with 188 species [69].

\section{Conclusion}

Urban tree plantation is desirable from both aesthetic and environmental perspectives. At present, Dhaka city has very small amount of green structure. Species composition and abundance decreasing continuously as areas are covered by different infrastructure. Exiting very little vegetation also not under well managed. During this study it was found that out of 27 registered park of DSCC, more than 10 parks have gone extinct due to illegal possession by rickshaw and car garage, restaurant, official club, kitchen market etc. which gradually shrinks the urban vegetative areas. Moreover, species composition in playground and garden are also not satisfactory. Roadside vegetation still in early stage. Fostering people's awareness, proper management by particular authority with strict government policy and law regarding urban vegetation could be a potential steps to establish and conserve vegetation spots. Considering the present situation of the urban vegetation of Dhaka south city corporation, it is need to suggest that appropriate planning and management technique like afforestation by different plant species, restoration of vegetation area are the effective modes to conserve biodiversity, functioning the natural ecosystem and improve urban tree coverage.

Acknowledgements Funding provided by Ministry of Science and Technology, Bangladesh.

Author Contributions: This work was carried out in collaboration with all authors. Author Md. Shahariar Jaman, Ishrat Jahan and Md. Forhad Hossain designed the study, analyzed the data, wrote the main protocol, and wrote the first and final draft. Author Mahbuba Jamil and Md. Javed Azad checked and evaluate the first and final draft. Author Md. Shariful Islam and Md. Golam Jilani Helal directly helped in field experiment. All authors read and approved the final manuscript.

Conflicts of Interest: The authors declare no conflict of interest 
396

397

398

399

400

401

402

403

404

405

406

407

408

409

410

411

412

413

414

415

416

417

418

419

420

421

422

423

\section{References}

1. Forrest, M.; Konijnendijk, C.C.; Randrup, T.B. COST Action E12-Research and Development in Urban Forestry in Europe. Official Printing Office of the European Communities, Luxembourg, 1999.

2. Coder, D.; Kim, D. Identified benefits of community trees and forests; Ph.D. Dissertation, University of Georgia, 1996.

3. Nowak, D.J.; Crane, D.E.; Stevens, J.C. Air pollution removal by urban trees and shrubs in the United States. Urban For. Urban Green. 2006, 4, 115-123.

4. Miller, R.W. Urban Forestry: Planning and managing urban green spaces. 2nd Ed. Prentice Hall, New Jersey, 1997.

5. Maco, S.E.; McPherson, E.G. A practical approach to assessing structure, function and value of street tree populations in small communities. J. Arboricul. 2003, 29, 9-84.

6. McPherson, E.; Nowak, D.J.; Rowntree, R.A.; Gordon, H. Quantifying urban forest structure, function, and value: the Chicago Urban Forest Climate Project. Urban Ecosyst. 1997, 14, 49- 61.

7. Heynen, N.C.; Lindsey, G. Correlates of urban forest canopy cover: implications for local public works. Public Work. Manag. Policy 2003, 8, 33-47.

8. Dobbs, C.; Escobedo, F.J.; Zipperer, W.C. A framework for developing urban forest ecosystem services and goods indicators. Landsc. Urban Plan. 2011, 99, 196-206.

9. Ramage, B.S.; Roman, L. Relationships between urban tree communities and the biomes in which they reside. Applied Veg. Sci. 2013, 16, 8-20.

10. Chen, S.S.; Jim, C.Y. Quantitative assessment of the treescape and cityscape of Nanjing, China. Landscape Ecol. 2003, 18, 395-412.

11. Zhao, M.; Escobedo, F.J.; Staudhammer, C.L. Spatial patterns of a subtropical, coastal urban forest: implications for land tenure, hurricanes, and invasive. Urban For. Urban Green. 2010, 9, 205-214.

12. Andreu, M.G.; Friedman, M.H,; Landry, S.M.; Northrop, R.J. City of Tampa urban ecological analysis 2006-2007; Final Report to the City of Tampa, Florida, 2008.

13. Rowntree, R.A. Ecology of the urban forest-part I: Structure and composition. Urban Ecol. 1984, 8, 1-178.

14. Nowak, D.J. Understanding the structure of urban forests. J. For. 1994, 92, 36-41.

15. Rowntree, R.A. Ecology of the urban forest- introduction to part II. Urban Ecol. 1986,

$$
\text { 9, 229-243. }
$$


430

431

432

433

434

435

436

437

438

439

440

441

442

443

444

445

446

447

16. Fahey, R.T.; Bowles, M.L.; Mcbride, J.L. Origins of the Chicago Urban Forest: Composition and structure in relation to pre-settlement vegetation and modern land use. Arboricul. E Urban For. 2012, 38, 181-193.

17. Shawn, M.L.; Robert, J.N.; Michael, G.A. The structure, composition, function and Economic benefits of trees and the urban forest. City of Tampa 2011 Urban Forest Analysis, September report, 2013.

18. Nowak, D.J.; Daniel, E.C.; Robert, E.H.; Jeffrey, T.W.; Jerry, B. A Ground-Based Method of Assessing Urban Forest Structure and Ecosystem Services. Arboricul. Urban For. 2008, 34, 347-358.

19. Jim, C.Y.; Liu, H.T. Species diversity of three major urban forest types in Guangzhou City, China. For. Ecol. Manag. 2001, 146, 99-114.

20. Godefroid. S.; Koedam, N. Distribution pattern of the flora in a peri-urbanforest: an effect of the city-forest eco tone. Landsc. Urban Plan. 2003, 65, 169-185.

21. Kendal, D.; Williams, N.S.G.; Williams, K.J.H. Drivers of diversity and tree cover in gardens, parks and streetscapes in an Australian city. Urban For. Urban Green. 2012, 11, 257-265.

22. Hasan, S.R. The failing city. New Age, http://www.newagebd.com/ April 23, 2012.

23. Dwyer, J.F.; Gregory, E.; Herbert, W.; Rowan, A. Assessing the benefits and costs of the urban forest. J. Arboricul. 1992, 18, 227-234.

24. Pauleit, S.; Jones, N.; Martin, G.G.; Valdecatos, G.L.J.; Riviere, M.L.; Beaudet, V.L.; Bodson, M.; Randrup, B.T. Tree establishment practice in town and cities-Results from A European survey. Urban For. Urban green. 2002, 1, 83-96.

25. Reddy, C.S. Catalogue of invasive alien flora of India. J. Life Sci. 2008, 5, 84-89.

26. Dhaka South City Corporation; http://www.dhakasouthcity.gov.bd. 2017.

27. Ibrahim, H.K. Basic information of Dhaka South City Corporation; the 3rd Asia smart City Conference (29-30 October), Yokohama, 2014.

28. Tawhid, K.G. Causes and effects of water logging in Dhaka City, Bangladesh. Ph.D. Dissertation, Department of Land and Water Resource engineering, Royal Institute of Technology, Stockholm, 2004.

29. United Nation Development Program. Land resources appraisal of Bangladesh for agricultural development. Report no. 2, Agro-ecological regions of Bangladesh, United Nations Development Programme, FAO, Rome, 1998; pp. 212-221.

30. Rahman, M.M.; Kabir, E.M.; Akon, U.J.M.S.A, Ando, K. High carbon stock in roadside plantation under participatory management in Bangladesh. Global Ecol. Conserve. 2015, 3, 412-423. 
31. Moore, P.D.; Chapman, S.B. Methods in Plant Ecology. Second edition, 1986.

32. Shukla, S.R.; Chandel, S.P. Plant ecol. 1980; 4thEdn. pp. 197.

33. Dallmeier, F. Long-term monitoring of biological diversity in tropical forest area. Mab. Digest. 1992, 9-71.

34. Ramadhanil, S.; Dede, S. Structure and composition of understory plant assemblages of Six land use types in the lore Lindu national park, Central Sulawesi, Indonesia. Bangladesh J. Plant. Taxon. 2008, 15, 1-12.

35. Pandey, S.K.; Shukla, R.P. Plant diversity in managed sal (Shorea robusta) forests of Gorakhpur, India: species composition, regeneration and conservation. Biodivers. conserve. 2003, 12, 2295-2319.

36. Diogo, J.S.; Alexandre, E.R.; Lima, D.O.; Carlos, L.F. Floristic composition and structure of an urban forest remnant of Fortaleza, Ceará. Gaia Scientia. 2014, 8, 266-278.

37. Zhu, H.N.; Xing, Y.H.; Chang, F.L.; Kamran, K.A. Assessing Urban Forest Structure and Health in Shenyang, China. Arboricul. Urban For. 2008, 34, 379-385.

38. Deb, J.C.; Halim, A. Density, diversity, composition and distribution of street trees in Sylhet Metropolitan City of Bangladesh. Int. J. Urban For. 2013. 35, 36-49.

39. Amin, M.; Alamgir. M.; Bhuiyan, M.R. Structural composition based on diameter and Height class distribution of a deforested area of Chittagong. Bangladesh. J. Applied Sci. 2005, 5, 227-231.

40. City of Sydney urban forest strategy; Adopted February, 2013.

41. Ricardo, D.; Vânia, R. P. Tree structure and species composition changes in an urban Tropical forest fragment (são paulo, Brazil) during a five-year interval. Boletim de Botânica da Universidade de São Paulo, 2002, 20, 1-12.

42. Nowak, D.J.; Cumming, A.B.; Twardus, D.; Hoehn, R.E.; Brandeis, T.J.; Oswalt, C.M. Urban Forests of Tennessee, 2009. U.S. Department of Agriculture and Forest Service, 2012, General technical report SRS-149, pp. 52.

43. Kim, G.; Miller, P.A.; Nowak, D.J. The Value of Green Infrastructure on Vacant and Residential Land in Roanoke, Virginia. Sustainability 2015, 8, 296.

44. Hartshorn, G.S. Neotropical forest dynamics. Biotropica (Supplement) 1980, 12, 23-30.

45. Lydia, C.; Jaume, T. Ecological Services of Urban Forest in Barcelona. Ph. D. Dissertation, Centre de Recerca Ecològica i Aplicacions Forestals, Universitat Autònoma de Barcelona, Spain, 2009.

46. Akbar, K.F.; Ashraf, I.; Shakoor, S. Analysis of urban forest structure, distribution and amenity value: a case study. J. Anim. Plant Sci. 2014, 24, 1636-1642. 
499

500

501

502

503

504

505

506

507

508

509

510

511

512

513

514

515

516

517

518

519

520

521

522

523

524

525

526

527

528

529

530

531

532

533

47. Hossain, M.A.; Hossain, M.K.; Alam, M.S.; Uddin, M.M. Composition and Diversity of Tree species in Kamalchari natural forest of Chittagong south forest division, Bangladesh. J. For. Environ. Sci. 2015, 31, 192-201.

48. Liu, C.; Li, X. Carbon storage and sequestration by urban forests in Shenyang, China. Urban For. Urban Green. 2012, 11, 121- 128.

49. Wang, Y.C. Carbon sequestration and foliar dust retention by woody plants in the greenbelt along two major Taiwan highways. Ann. Appl. Biol. 2011, 159, 244-251.

50. Rahman, M.A.; Rashid, M.H.; Wilcock, C.C. Diversity, ecology, distribution and ethnobotany of the apocynaceae of Bangladesh. Bangladesh J. Plant. Taxon. 2000, 7, 5776.

51. Wale, H.A.; Bekele, T.; Dalle, G. Floristic diversity, regeneration status and vegetation structure of woodlands in Metema area, Amhara National Regional State, Northwestern Ethiopia. J. For. Res. 2012, 23, 391-398.

52. Shukla, R.P.; Pandey, S.K. Plant diversity and community features of the forested landscape adjacent to foot-hills of Central Himalayas. In: Natural resources, conservation and management for mountain development. 2000, Tiwari SC, Dabral PP (eds).

53. Bekele, T. Vegetation ecology of remnant afromontane forests on the central plateau of Shewa, Ethiopia; Ph.D. Dissertation, Uppsala University, 1993.

54. Ayalew, A. A floristic composition and structural analysis of the Denkoro Forest, South Wello; MSc Thesis, Addis Ababa University, 2003.

55. Zegeye, H.; Teketay, D.; Kelbessa, E. Diversity and regeneration status of woody species in Tara Gedam and Abebaye forests, northwestern Ethiopia. J. For. Res. 2011, 22, 315328.

56. Rahman, M.L.; Hossain, M.K. Status of fodder and non-fodder tree species in Chunati Wild life sanctuary of Chittagong forest division, Bangladesh. Int. J. For. Usuf. Manage. 2003, 4: 9-14.

57. Hossain, M.A.; Hossain, M.K.; Salam, M.A.; Rahman, S. Composition and diversity of tree species in dudhpukuria-dhopachori wildlife sanctuary of Chittagong (south) forest division, Bangladesh. Res. J. Pharma. Biol. Chem. Sci. 2013, 4, 1447-1457.

58. Nath, T.K.; Hossain, M.K.; Alam, M.K. Diversity and composition of trees in Sitapahar Forest reserve of Chittagong Hill Tracts (South) forest division Bangladesh. Ann. For. $1998,6,1-9$.

59. Motaleb, M.A.; Hossain, M.K. Assessment of tree species diversity of Tankawati natural forests, Chittagong (South) Forest Division, Bangladesh. J. Eco-Friendly Agri. 2011, 4, $542-545$. 
534

535

536

537

538

539

540

541

542

543

544

545

546

547

548

549

550

551

552

553

554

555

556

557

558
60. Okiror, P.; Chono, J.; Nyamukuru, A.; Lwanga, J.S.; Sasira, P.; Diogo, P. Variation in Woody Species Abundance and Distribution in and around Kibale National Park, Uganda. ISRN. For. 2012, 20, 1-9.

61. Giliba, R.A.; Boon, E.K.; Kayombo, C.J.; Musamba. E.B.; Kashindye, A.M.; Shayo, P.F. Species Composition, Richness and Diversity in Miombo Woodland of Bereku Forest Reserve, Tanzania. Acta. Amazonica. 2011, 2, 43-22.

62. Kent, M.; Coker, P. Vegetation description and analysis : a practical approach, (2nd Ed.) Ghent University Library, London, 1992.

63. Muthuramkumar, S.; Parthasarathy, N. Alpha diversity of lianas in a tropical evergreen Forest in the Anamalais of Western Ghats, India. Diver. Distri. 2000, 6, 1-14.

64. Nagendra, H.; Gopal, D. Tree diversity, distribution, history and change in urban parks: studies in Bangalore, India. Urban Ecosyst. 2010, 14, 211-223.

65. Uddin, N.M.; Alam, O.; Uddin, M.M.; Hoque, A.R. Diversity and distribution of tree Species in the hills of Chittagong Metropolitan Area, Bangladesh. J. Biodivers. Env. Sci. 2015, 6, 89-99.

66. Lilia. B.; Bearder, K.S.; Gunawardene, A. Habitat Use by the Red Slender Loris (Loris tardigradus tardigradus) in Masmullah Proposed Forest Reserve in Sri Lanka. Advances Prosimian Biol. 2012, 10, 79-87.

67. Godwin, E. Tree Species composition and diversity in oban Forest Reserve, Nigeria. J. Agric. Studies 2015, 3, 10-24.

68. Cynnamon, D.B.; DaveKendalc, C.N. The effects of land tenure and land use on the urban forest structure and composition of Melbourne. Urban For. Urban Green. 2013, 12, 417425 .

69. Wangai, W.P.; Burkhard, B.; Muller, F. A review of studies on ecosystem services in Africa. Int. J. Sus. Built Environ. 2016, 5, 225-245. 